\title{
Diesel Emission with DPF+SCR in VERTdePN - Testing \& Potentials
}

Jan Czerwinski and Yan Zimmerli

Univ. of Applied Sciences - Biel

Andreas Mayer

TTM

Norbert Heeb

EMPA

\section{Giovanni D'Urbano}

Swiss Federal Office for the Environment

\begin{abstract}
The most efficient way and the best available technology (BAT) to radically reduce the critical Diesel emission components particles (PM\&NP) and nitric oxides $\left(\mathrm{NO}_{\mathrm{x}}\right)$ are combined exhaust gas aftertreatment systems (DPF+SCR). SCR (selective catalytic reduction) is regarded as the most efficient deNO ${ }_{x}$-system, diesel particle filters are most efficient for soot abatement. Today, several suppliers offer combined systems for retrofitting of HD vehicles.
\end{abstract}

The presented results are part of the work in the international network project VERT ${ }^{*}$ ) dePN (de-activation, decontamination, disposal of particles and $\mathrm{NO}_{\mathrm{x}}$ ), which has the objectives to establish test procedures and quality standards and to introduce the SCR-, or combined DPF+SCR-systems in the VERT verification procedure.

Examples of results for some of the investigated systems are given and the most important findings are:
- the average $\mathrm{NO}{ }_{\mathrm{x}}$ conversion rate at transient operation strongly depends on the operation load profile, on the exhaust gas temperature and the resulting urea dosing control,

- the particle number filtration efficiency, which is verified at stationary engine operation, is valid also at the transient operation,

- secondary nanoparticles are produced due to urea injection, they nevertheless do not impact significantly the overall filtration efficiency of the system (here: DPF upstream \& SCR downstream, differences of PCFE in the range of $0.1 \%$ ),

- the OEM NO ${ }_{x}$-sensors of the investigated systems are appropriate tools for the in-use control,

- the system with catalyzed DPF (upstream) attains higher overall deNO ${ }_{x}$-efficiencies due to $\mathrm{NO}_{2}$-production in the DPF,

- for the investigated systems there are no critical emissions of unregulated components, $\mathrm{NH}_{3} \& \mathrm{~N}_{2} \mathrm{O}$. 


\section{INTRODUCTION \& OBJECTIVES}

Laboratories for IC-Engines and Exhaust Emission Control of the University of Applied Sciences Biel, Switzerland (AFHB) participate since 1992 at the Swiss activities about nanoparticle analytics and DPF verification.

The upcoming developments of $\mathrm{deNO}_{\mathrm{x}}$ (especially SCR) systems and the combinations with DPF's offer a large number of variants and technical complexity representing new challenges not only for the manufacturers, but also for the users and for the responsible authorities.

The Swiss Federal Office of Environment BAFU and the Swiss Federal Roads Office ASTRA decided to support further activities of VERT to develop appropriate testing procedures and to define the quality criteria of dePN systems for retroffiting.

In the VERTdePN project AFHB collaborates closely with several Swiss specialists of chemistry, catalysis, measuring techniques and combisystems (EMPA, PSI, SUVA, ME, UMTEC), as well as European specialist from JRC Ispra, I; TNO \& VROM, NL; AEEDA, B; FAD and TÜV D; AKPF, $\mathrm{A}$ and the VERT Association, $\mathrm{CH}$.

The application of combined systems (DPF+SCR) as retrofitting devises raises different technical and commercial problems. In general opinion, this retofitting will be possible mostly through incentives, or restrictions with respect to low emission zones LEZ, [1] and new regulations of the respective authorities.

The combination of diesel particle filters (DPF) and $\mathrm{deNO}_{\mathrm{x}}$ technology (SCR) is widely considered as the best solution, up to date, to minimize the emissions of Diesel engines. Intense developments are on the way by the OEM's and a lot of research is performed on the implementation of such technologies $[\underline{2}, \underline{3}, \underline{4}, \underline{5}, \underline{6}, \underline{7}, \underline{8}, \underline{9}, \underline{10}, \underline{11}, \underline{12}, \underline{13}, \underline{14}]$.

The removal of $\mathrm{NO}_{\mathrm{x}}$ from lean exhaust gas of Diesel engines (also lean-burn gasoline engines) is a challenge. Selective catalytic reduction (SCR) uses a supplementary substance, a reducing agent, which in presence of catalysts supports the transformation of $\mathrm{NO}_{\mathrm{x}}$ in $\mathrm{N}_{2}$ and $\mathrm{H}_{2} \mathrm{O}$.

The preferred reducing agent for toxicological and safely reasons is a water solution of urea (AdBlue), which after thermal decomposition and hydrolysis decomposes to ammonia $\mathrm{NH}_{3}$, the actual reducing agent.

Diesel Particle Filter (DPF) eliminate very efficiently the particle mass and the nanoparticles from exhaust gas.
The filtration efficiency of a DPF can be properly judged only for the solid particles. In this context the nanoparticles are considered in VERT/LRV as the most important criterion, $[\underline{15}, \underline{16}]$.

Nanoparticles can be measured with different methods and due to the aptitude of penetrating very easily into living organisms they are regarded as dangerous for health, $[\underline{17}, \underline{18}$, 19].

The present paper shows some research results on different combined systems (DPF+SCR) in the VERTdePN project and is related previous work [20].

Herein we will discuss new findings on:

- results in different dynamic test cycles,

- emissions of secondary nanoparticles,

- results obtained in the urea switch-on tests,

- comparisons of different investigated systems.

\section{TEST-ENGINE, FUEL AND LUBRICANT}

\section{TEST ENGINE}

There are following engine data:

$\begin{array}{ll}\text { Manufacturer: } & \text { Iveco, Torino Italy } \\ \text { Type: } & \text { F1C Euro 3 } \\ \text { Displacement: } & 3.00 \text { Liters } \\ \text { RPM: } & \text { max. } 4200 \mathrm{rpm} \\ \text { Rated power: } & 100 \mathrm{~kW} @ 3500 \mathrm{rpm} \\ \text { Model: } & 4 \text { cylinder in-line } \\ \text { Combustion process: } & \text { direct injection } \\ \text { Injection system: } & \text { Bosch Common Rail / } 1600 \text { bar } \\ \text { Supercharging: } & \text { turbocharger with intercooling } \\ \text { Emission control: } & \text { none } \\ \text { Development period: } & \text { until } 2000 \text { (Euro 3) }\end{array}$

Fig. 1 shows the engine and the equipment for nanoparticle analyses. A SMPS \& NanoMet was used at the AFHB. 


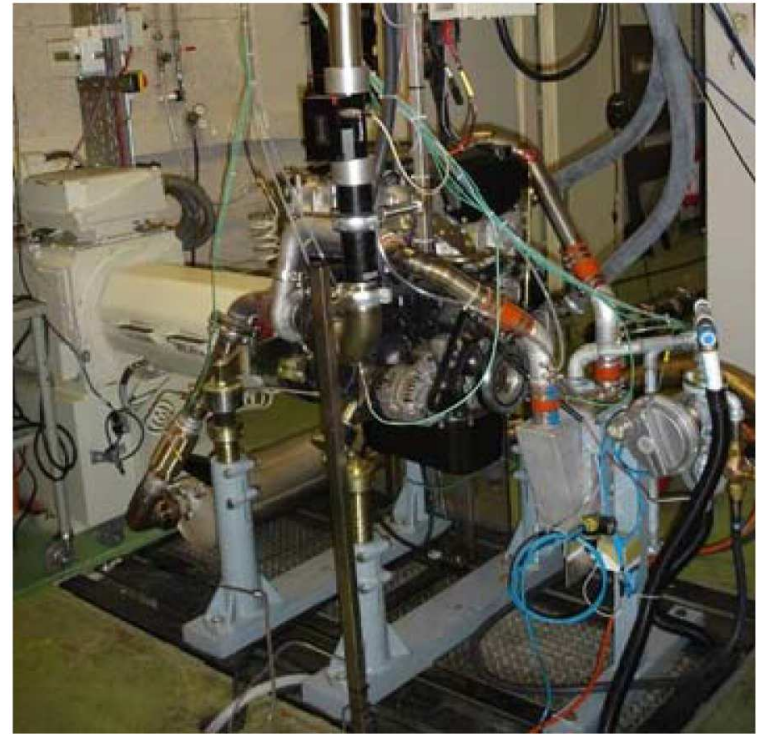

Fig.1a. IVECO engine FC1 with the dynamic Dynamometer

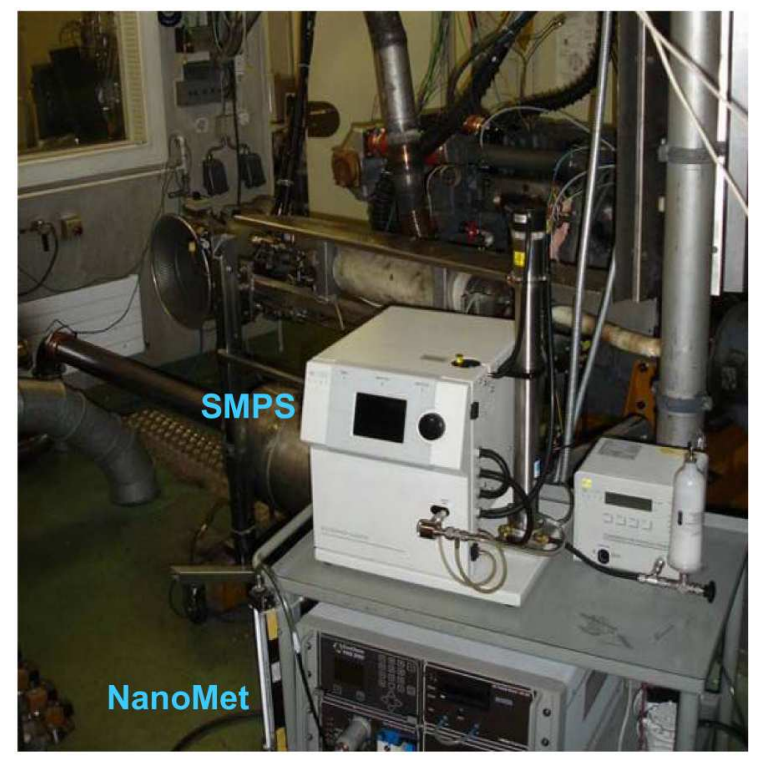

Fig. 1b. Equipment for nanoparticle measurements in the engine room

\section{FUEL}

Table 1 represents the most important data of the fuel, which was a commercial Shell Formula Diesel fuel with Swiss summer quality (10 ppm S) according to SN EN 590
Table 1. Fuel properties as per EU-standards (EN)

\begin{tabular}{|lr|c|}
\hline & & \multicolumn{1}{|c|}{ Diesel } \\
\hline Density at $15^{\circ} \mathrm{C}$ & $\mathrm{g} / \mathrm{m}$ & $0.842^{*}$ \\
\hline Viscosity at $40^{\circ} \mathrm{C}$ & $\mathrm{mm}^{2} / \mathrm{s}$ & $2.0-4.5$ \\
\hline Flash point & & above $55^{\circ} \mathrm{C}$ \\
\hline Cloud point & & $\max -10^{\circ} \mathrm{C}$ \\
\hline Filterability CFPP & & $\max -20^{\circ} \mathrm{C}$ \\
\hline Ash & $\mathrm{ppm}$ & $\max 0.010$ \\
\hline Sulfur & & $<10$ \\
\hline Cetane Number & $\mathrm{MJ} / \mathrm{kg}$ & 42.7 \\
\hline Calorific value & in $\%$ & 86.7 \\
\hline C fraction & in $\%$ & 13.3 \\
\hline H fraction & in $\%$ & 0 \\
\hline O fraction & $\mathrm{kg} / \mathrm{kg}$ & 14.52 \\
\hline Air / Fuel stoichiom & & $180-340$ \\
\hline Boiling range $10-90 \%{ }^{\circ} \mathrm{C}$ &
\end{tabular}

\section{LUBRICANT}

For all tests a lubricating oil Mobil 1 ESP Formula 5W-30 was used. This oil is recommended by the engine manufacturer.

Table 2. Data of the applied lubrication oil (EN)

\begin{tabular}{|l|c|l|}
\hline Property & Mobil & \\
\hline Viscosity kin $40^{\circ} \mathrm{C}$ & 72.8 & $\mathrm{~mm}^{2} / \mathrm{s}$ \\
\hline Viscosity kin $100^{\circ} \mathrm{C}$ & 12.1 & $\mathrm{~mm}^{2} / \mathrm{s}$ \\
\hline Viscosity index & 164 & $(--)$ \\
\hline Density $15^{\circ} \mathrm{C}$ & 0.850 & $\mathrm{~kg} / \mathrm{m}^{3}$ \\
\hline Pourpoint & -45 & ${ }^{\circ} \mathrm{C}$ \\
\hline Flamepoint & 254 & ${ }^{\circ} \mathrm{C}$ \\
\hline Total Base Number TBN & 14.2 & $\mathrm{mg} \mathrm{KOH} / \mathrm{g}$ \\
\hline Sulfur ashes & 6000 & $\mathrm{mg} / \mathrm{kg}$ \\
\hline Sulfur & $7 ' 280$ & $\mathrm{mg} / \mathrm{kg}$ \\
\hline $\mathrm{Mg}$ & $<10$ & $\mathrm{mg} / \mathrm{kg}$ \\
\hline $\mathrm{Zn}$ & $1^{\prime} 570$ & $\mathrm{mg} / \mathrm{kg}$ \\
\hline Ca & $4^{\prime} 760$ & $\mathrm{mg} / \mathrm{kg}$ \\
\hline $\mathrm{P}$ & $1^{\prime} 370$ & $\mathrm{mg} / \mathrm{kg}$ \\
\hline
\end{tabular}

$\underline{\text { Table } 2}$ shows the available data of this oil,

ACEA classes: C3, A3, B3/B4,

API classes: SL / SM; CF 


\section{MEASURING SET-UP AND INSTRUMENTATION}

\section{ENGINE DYNAMOMETER AND STANDARD TEST EQUIPMENT}

Fig. 2 represents the equipement installed on the engine, or in its periphery for analysis of the regulated and unregulated emissions.

Laboratory equipment employed:

- Dynamic test bench Kristl \& Seibt with force transducer HBM T10F

- Tornado Software Kristl \& Seibt

- Fuel flow measurement AIC 2022

- Air mass meter ABB Sensiflow P

- Pressure transducers Keller KAA-2/8235, PD-4/8236

- Thermo-couples Type K.

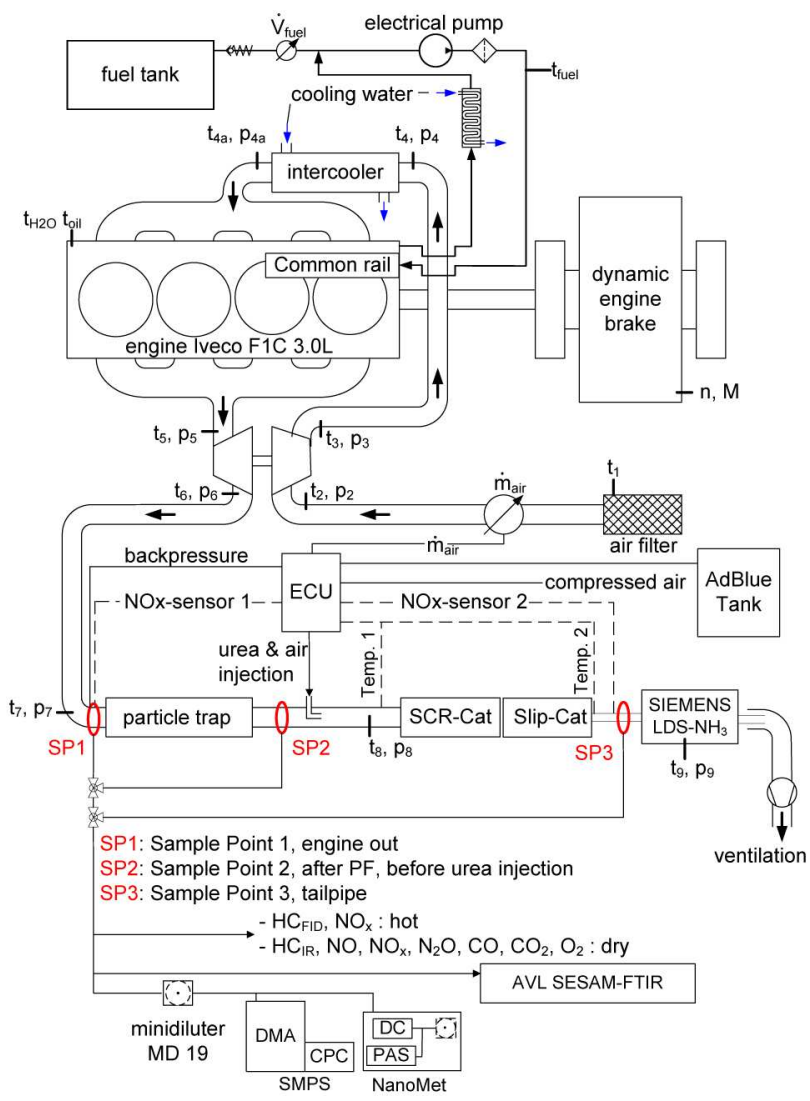

Fig. 2. Engine dynamometer and test equipment

\section{TEST EQUIPMENT FOR EXHAUST GAS EMISSIONS}

Measurements are performed according to the exhaust gas emissions regulations for heavy duty vehicles, which are valid for Switzerland (Directive 2005/55/EC \& ISO 8178):
- Volatile components:

- Horiba exhaust gas measurement devices

- Type: VIA-510 for $\mathrm{CO}_{2}, \mathrm{CO}, \mathrm{HC}_{\mathrm{IR}}, \mathrm{O}_{2}$,

- Type: CLA-510 for NO, NOx (this standard hot analyser with one reactor is marked in this report as "1 CLD")

- Amluk exhaust gas measurement device Type: FID 2010 for $\mathrm{HC}_{\mathrm{FID}}$,

- $\mathrm{NH}_{3}$ and $\mathrm{N}_{2} \mathrm{O}$ :

- With SCR several unregulated and secondary pollutants can be produced. The slip of gaseous components such as ammonia $\mathrm{NH}_{3}$ and nitrous oxide $\mathrm{N}_{2} \mathrm{O}$ was measured by means of:

- Siemens LDS 6 Laser Analyzer 7MB 6021, $\mathrm{NH}_{3}$

- Siemens ULTRAMAT 6E 7MB2121, $\mathrm{N}_{2} \mathrm{O}$

- Eco physics CLD $822 \mathrm{CM}$ hr with hot line for NO, $\mathrm{NO}_{2}, \mathrm{NO}_{3}, \mathrm{NH}_{3}$ (this analyzer with two reactors is marked in this report as " 2 CLD")

- FTIR (Fourier Transform Infrared) Spectrometer (AVL SESAM) with the possibility of simultaneous, time-resolved measurement of approx. 30 emission components - among those validated are: $\mathrm{NO}, \mathrm{NO}_{2}, \mathrm{NO}_{\mathrm{x}}, \mathrm{NH}_{3}, \mathrm{~N}_{2} \mathrm{O}$.

\section{PARTICLE SIZE ANALYSIS}

To estimate the filtration efficiency of the DPF, as well as to detect the possible formation of secondary nanoparticles, the particle size and number distributions were analysed with the following equipement, Fig. 1b:

- SMPS - Scanning Mobility Particle Sizer, TSI (DMA TSI 3081, CPC TSI 3010)

- NanoMet - System consisting of:

- PAS - Photoelectric Aerosol Sensor (Eco Chem PAS 2000) indicates the carbonaceous total surface of the aerosol

- DC - Diffusion Charging Sensor (Matter Eng. LQ1-DC) indicates the totale surface of the aerosol independently of the chemical properties

- MD19 tunable minidiluter (Matter Eng. MD19-2E)

- Thermoconditioner (TC) (i.e. MD19 + post-dilution sample heating until $300^{\circ} \mathrm{C}$ ).

A minidiluter MD19 with thermoconditioner $\left(300^{\circ} \mathrm{C}\right)$ was used to sample nanoparticles at the tail pipe. Nanoparticle measurements were performed at constant engine speed 
(warm) with SMPS and NanoMet. During dynamic engine operation, NanoMet and CPC were used.

This NP measuring set-up is in accordance with the requirements of the EC GRPE Particle Measuring Program (PMP).

\section{TEST PROCEDURES}

The dynamic testing was started with the European Transient Cycle ETC and continued with the WHTC (worldwide heavy duty transient cycle), Fig. 3. Also two city-bus cycles: NYCC (New York City Cycle) and Braunschweig Bus Cycle were investigated. All these cycles were defined on the basis of the full (non-limited) engine map. They cause very different operating conditions of the engine, which is depicted with different profiles of exhaust gas temperatures at the tailpipe (Fig. 3, bottom).

The tests were performed after a warm-up phase, when the engine coolant temperature and lube oil temperature reached their stationary values (stationary points tests).

Before starting a dynamic cycle the same conditioning procedure was used to stabilize the thermal conditions of the exhaust gas aftertreatment system. This conditioning was: 5 min at point $1(2200 \mathrm{rpm} / \mathrm{FL})$ and $0.5 \mathrm{~min}$ of idling.

For the low-load cycles (NYCC and Braunschweig), the conditioning was: $5 \mathrm{~min} 1600 \mathrm{rpm} / 165 \mathrm{Nm}$ and $0,5 \mathrm{~min}$ idling.

For the tests concerning: filtration efficiency, secondary NP, deNO ${ }_{\mathrm{x}}$-rate, unregulated parameters, some basic studies on the investigated systems were performed in the 4-points test according to VPNT1.

These operating points are (in the following sequence):

- operating point 7: 50\% load, intermediate speed 1, 1600 $\mathrm{rpm} / 50 \%$,

- operating point 4: $10 \%$ load, intermediate speed 2, 2200 $\mathrm{rpm} / 10 \%$,

- operating point 1: 100\% load, intermediate speed 2, 2200 $\mathrm{rpm} / 100 \%$,

- operating point 3: 50\% load, intermediate speed 2, 2200 $\mathrm{rpm} / 50 \%$,

- operating point 7: repetition.
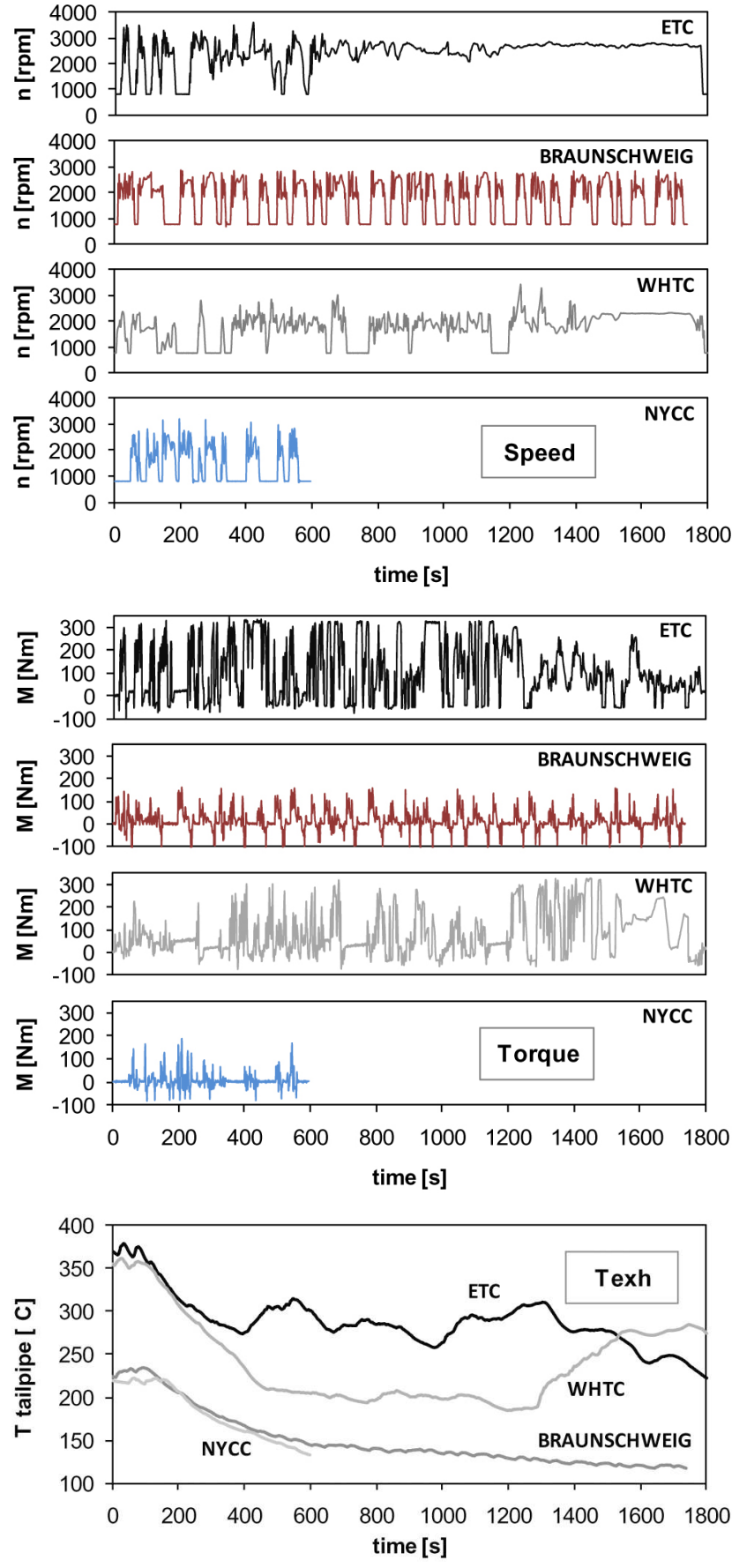

Fig. 3. Speed, torque and exhaust temperature in the investigated dynamic test cycles

These four operating points were chosen to study the effects of "off" and "on" switching of the urea-dosing (pt. $7 \rightarrow$ pt. 4 and pt. $4 \rightarrow$ pt. 1).

Different sampling positions (SP) were used to analyse exhaust compositions and temperatures in more detail (see Fig. 2): 
- SP 0 sampling engine out w/o aftertreatment system

- SP 1 sampling engine out with aftertreatment system

- SP 2 sampling after DPF (before urea dosing) with aftertreatment system

- SP 3 sampling at tailpipe with aftertreatmentsystem.

This designation of sampling positions is used in the presented figures and in the discussion of results.

Another useful procedure is the urea switch-on test (SW). This test consists of a warm-up of the engine in a low load operation point, without any urea injection, and then increasing the engine load in a controlled way to an engine load where urea injection starts.

This quite simple procedure can be repeated during each warm-up of the engine and of the exhaust system. The SWtest can be joint with the OEM datalogging and it gives additional information on the extent of emissions and $\mathrm{NO}_{\mathrm{x}}$ reduction efficiency. The urea switch-on test is considered as a simple and reliable check of SCR quality on vehicles (chassis dyno).

For testing the passive regeneration of DPF's and the $\mathrm{NO}_{2}$ increase of catalyzed DPF-systems according to the VERT/ LRV procedures, a steps-test, Fig. 4, is also used. This test was performed in the present work to correlate the emissions and exhaust gas temperatures at $2200 \mathrm{rpm}$ with increasing engine laod: $10 \%, 20 \% 30 \%, 40 \% 50 \%, 75 \%$ and $100 \%$.

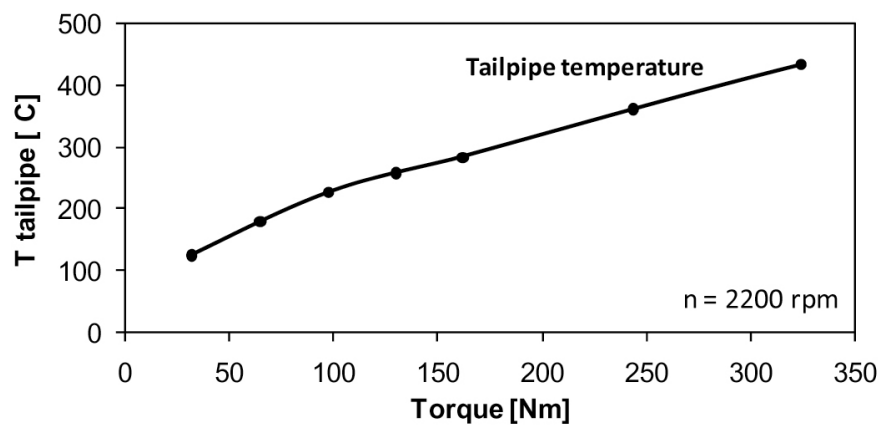

Fig. 4. Torque \& exhaust temperature in the steps-test

\section{5. (DPF+SCR) SYSTEMS}

A combined system consisting of a DPF upstream of the urea dosing point and a vanadium-based SCR catalyst downstream of the filter was used (as in Fig. 2).

A mixing tube of $1.0 \mathrm{~m}$, without mixer was used between the DPF and SCR.
In certain experiments, an ammonia slip catalyst was used at the tail pipe. The combined DPF+SCR system is designed for transient application with an electronic control unit, using the signals of: air flow, $\mathrm{NO}_{\mathrm{x}}$ before/after system, and temperatures before/after the SCR catalyst.

Following three variants were investigated:

- PF1 + SCR

- PF1 + SCR + slip cat.

- PF3 + SCR

PF1 is a catalytically coated Cordierite DPF, PF3 is a uncoated $\mathrm{SiC}$ DPF with FBC (40 ppm Fe, double dosing for testing purposes). Both DPF's are VERT-approved with average NP filtration efficiencies FE $>99 \%$.

A feed factor of $\alpha=0.9$ was generally used (during investigations on secondary nanoparticles in Fig. $7 \& \underline{8}$ a feed factor $\alpha=1.0$ was applied).

\section{RESULTS}

\section{DIFFERENT TEST CYCLES}

Tests were performed with different driving cycles with non limited engine map (NEM).

The exhaust temperatures at the tailpipe over cycle time for all investigated test cycles are given in Fig. 3 together with engine speed and torque.

Fig. 5 summarizes average exhaust concentrations for the different test cycles and Fig. 6 shows the conversion efficiencies in different driving cycles.

In Table 3 the fuel consumption and the average exhaust temperatures in all driving cycles are represented.

The New York City Cycle (NYCC) and the Braunschweig cycle are low-load cycles, which were developed in those cities and represent the city bus driving.

Exhaust temperatures in these low load cycles are too low ( $<$ $200^{\circ} \mathrm{C}$ ) to enable the full working potential of the SCRsystem. The urea injection is usually cut off at $\mathrm{t}_{\mathrm{exh}} 190-200^{\circ} \mathrm{C}$ to prevent the deposition of solid matter in the system.

Average $\mathrm{NO}_{\mathrm{x}}$ emissions in the low load cycles are lower too, but there is also a poor $\mathrm{NO}_{\mathrm{x}}$-conversion due to the urea dosing strategy. 

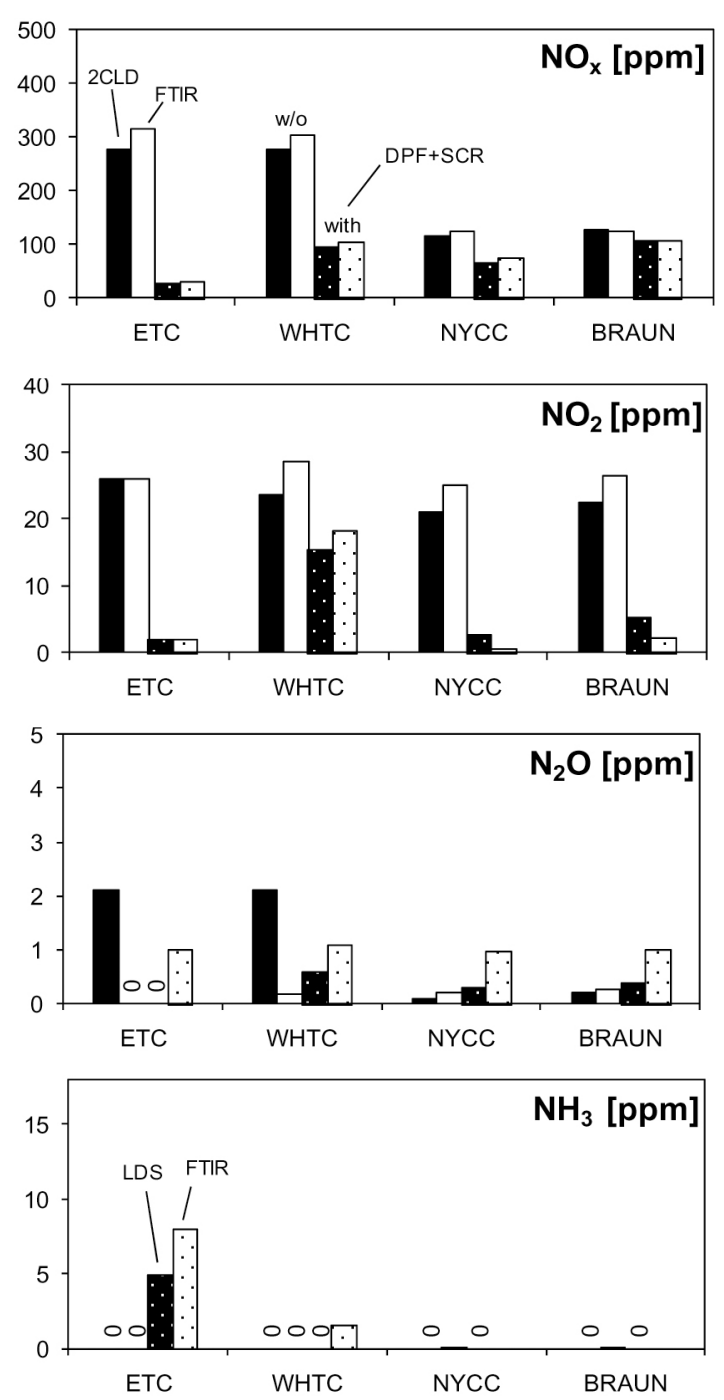

Fig. 5. Integral average emission values in dynamic cycles, PF1+SCR, $\alpha=0.9$

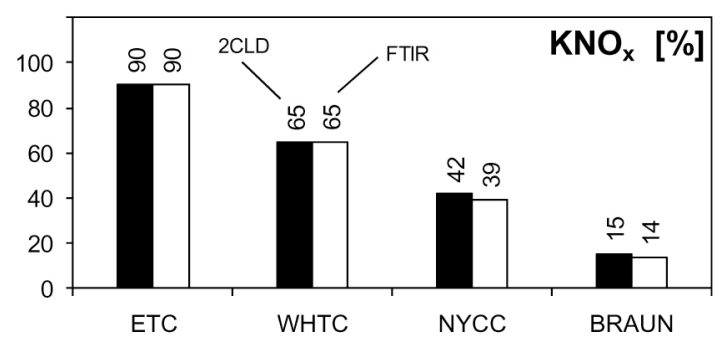

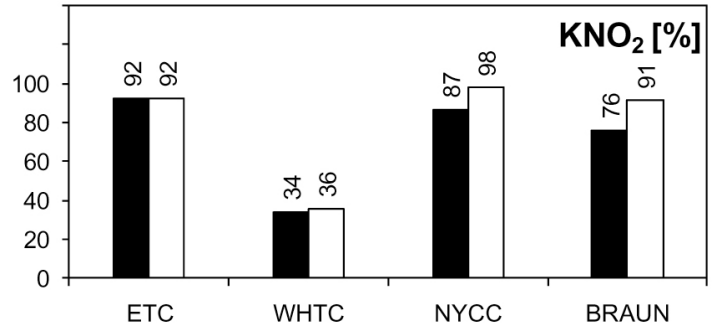

Fig. 6. Comparison of reduction efficiencies in dynamic cycles, PF1+SCR, $\alpha=0.9$

Table 3. Fuel consumption and average exhaust temperatures in different driving cycles, PF1+SCR, $\alpha=0.9$

\begin{tabular}{|l|c|c|c|c|c|c|c|c|}
\cline { 2 - 9 } \multicolumn{1}{c|}{} & \multicolumn{2}{c|}{ ETC } & \multicolumn{2}{c|}{ WHTC } & \multicolumn{2}{c|}{ NYCC } & \multicolumn{2}{c|}{ Braunschweig } \\
\cline { 2 - 9 } & \multicolumn{2}{c|}{$1800 \mathrm{~s}$} & \multicolumn{2}{c|}{$1800 \mathrm{~s}$} & \multicolumn{2}{c|}{$598 \mathrm{~s}$} & \multicolumn{2}{c|}{$1740 \mathrm{~s}$} \\
\cline { 2 - 9 } & OEM & $\begin{array}{c}\text { DPF+ } \\
\text { SCR }\end{array}$ & OEM & $\begin{array}{c}\text { DPF+ } \\
\text { SCR }\end{array}$ & OEM & $\begin{array}{c}\text { DPF+ } \\
\text { SCR }\end{array}$ & OEM & $\begin{array}{c}\text { DPF+ } \\
\text { SCR }\end{array}$ \\
\hline Fuel [I/test] & 4.15 & 4.30 & 2.58 & 2.64 & 0.25 & 0.26 & 1.02 & 1.05 \\
\hline T Engine Out [ $\left.{ }^{\circ} \mathrm{C}\right]$ & 282 & 310 & 247 & 261 & 144 & 151 & 149 & 156 \\
\hline T Tailpipe $\left[{ }^{\circ} \mathrm{C}\right]$ & 248 & 291 & 210 & 241 & 139 & 182 & 127 & 150 \\
\hline
\end{tabular}

$\mathrm{N}_{2} \mathrm{O}$ emissions are generally very low $(<2 \mathrm{ppm})$ and $\mathrm{NH}_{3}$ was found only in ETC with $\mathrm{SCR} \mathrm{NH} \mathrm{NH}_{3}$ but its concentrations are typically $<8 \mathrm{ppm}$ at urea feed factors of 0.9 .

Comparing different measuring techniques as shown in $\underline{\text { Figures } 5} \& \underline{6}$ one can conclude:

- good correlation of $\mathrm{NO}_{\mathrm{x}} \& \mathrm{NO}_{2}$ measured with FTIR and with two CLD,

- good correlation of $\mathrm{NH}_{3}$ measured with FTIR and with LDS,

- poor correlation of $\mathrm{N}_{2} \mathrm{O}$ measured with FTIR and with ULTRAMAT; This is the case, because $\mathrm{N}_{2} \mathrm{O}$ concentrations are low - mostly at the detection limits of the analytical devises,

- the relative values, like conversion efficiencies $\mathrm{K}_{\mathrm{x}}$ are well correlated with all measuring methods.

These conclusions are supported from several other internal investigations not presented in this paper.

Finally we conclude that the investigated SCR-system has low $\mathrm{NO}_{\mathrm{x}}$ conversion efficiencies of 40 and $15 \%$ in both lowload city driving cycles. This has been observed before, when comparing the NOx emissions of the high-load-ETC (nonlimited engine map NEM) with those in the low-load-ETC (limited engine map LEM [20]). 


\section{SECONDARY NANOPARTICLES}

The production of secondary nanoparticles downstream of the urea dosing point was noticed earlier [20]. Such nanoparticles are possibly formed during the deNOx process. The chemical composition of these particles is yet unknown and further investigations are on the way. They may consist of unreacted urea or derivatives thereof such as cyanuric acid, or salts from acidic and basic compounds such as ammonium nitrite, nitrate, and sulfates and others.

In the present status of these investigations, the objective was to systematically study the number and particle size of these secondary NP by means of PM, SMPS and NanoMet at sampling positions SP2 \& SP3, (SP2 ... after DPF \& before urea dosing, SP3 ... after SCR).

SMPS measurements after the DPF (SP2) and after the SCR (SP3) confirmed the presence of secondary nanoparticles in all load stages of the 4-points test.

Fig. 7 shows an example of the SMPS size distributions and the integrated particle number in different parts of the size spectra at $2200 \mathrm{rpm} / 50 \%$. The increase of particle mass emissions between SP2 and SP3 as a result of a secondary particles formation was noticed as well.

Fig. 8 represents the particle mass PM, the mass-related filtration-efficiency PMFE and the particle number related filtration efficiency PCFE in all operating points and at all sampling positions SP0, SP2 \& SP3. At two OP's, there is a little, but consistent increase of PM between SP2 and SP3. This causes a significant reduction of PMFE, but no significant reduction of PCFE. This indicates that these secondary particles mainly contribute to particle mass but not much to particle numbers.

It can be summarized that the presence of secondary nanoparticles after the SCR-system was confirmed. In some cases, secondary NP contribute to an increase of the particle mass.

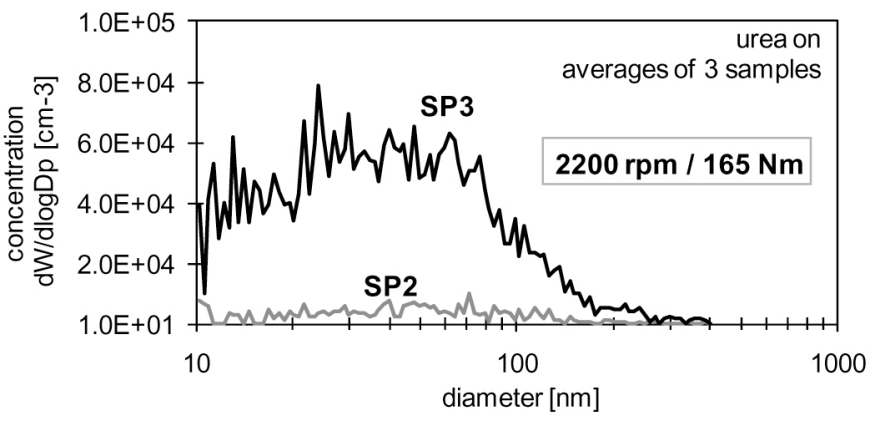

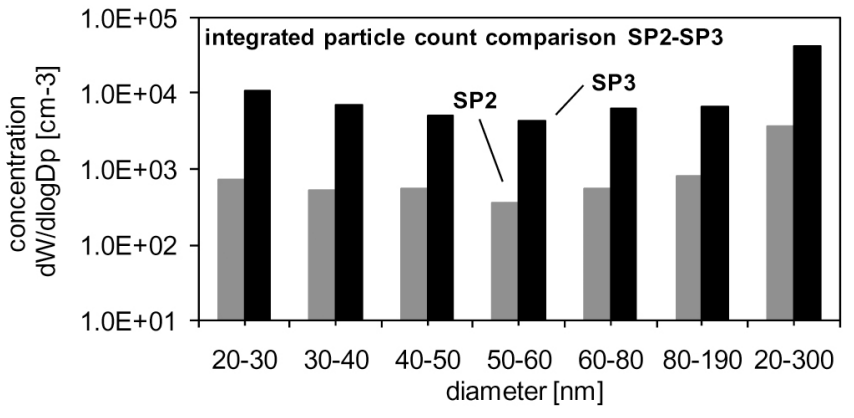

Fig. 7. SMPS-size spectra at SP2 \& SP3, PF1+SCR, $\alpha=1.0$
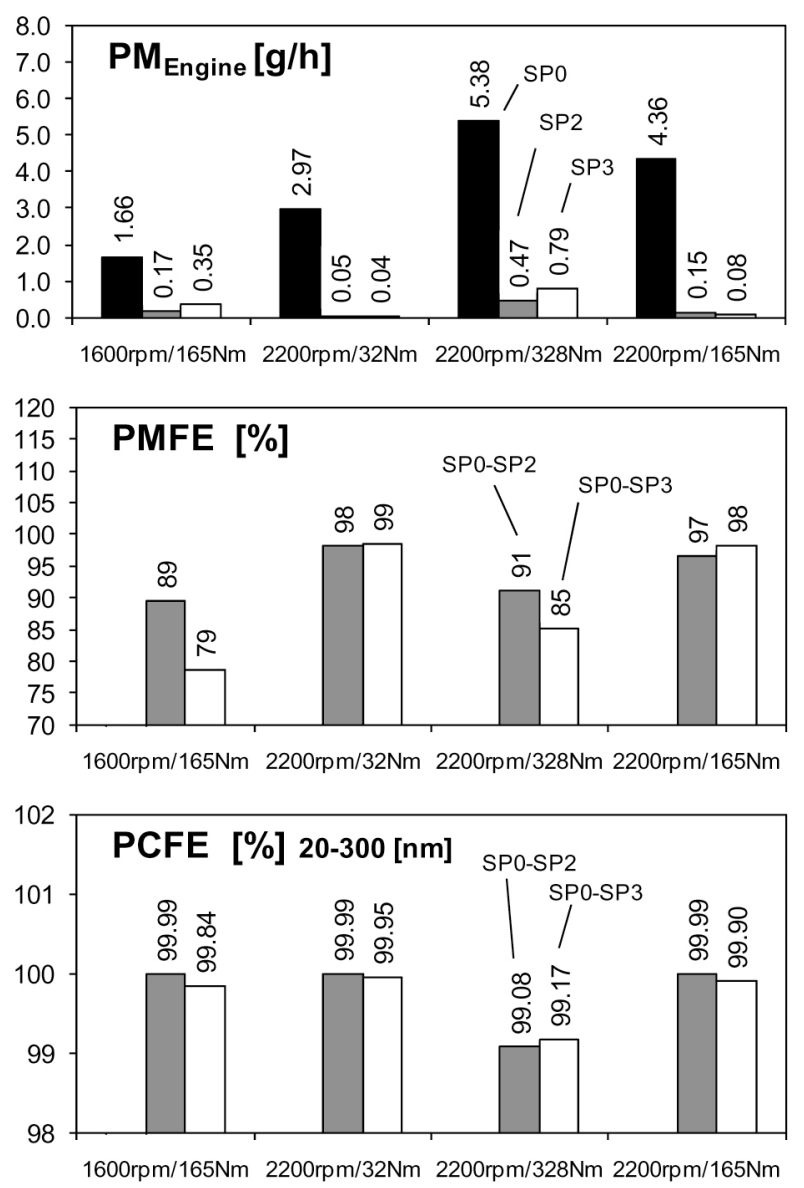

Fig. 8. Particle mass and counts reduction in the 4 points test, PF1+SCR, $\alpha=1.0$

\section{UREA SWITCH-ON TESTS}

The urea switch-on test (SW) was developed to study effects during the SCR light-off. Engine and exhaust system in this test are warmed up at a low load OP (e.g. $1200 \mathrm{rpm} / 60 \mathrm{Nm}$ ) without urea injection. After a jump to higher engine loads OP (e.g. $1600 \mathrm{rpm} / 165 \mathrm{Nm}$ ), urea injection is activated. 
In the $1^{\text {st }}$ operating point the engine slowly warms up, but the exhaust gas temperature is still too low to allow urea injection. After a jump to higher loads, the $2^{\text {nd }}$ operating point, urea injection is activated after certain time after the exhaust temperature $t_{\mathrm{exh}}$ has increased.

Measurements were started shortly before the load jump to register the changes of exhaust concentrations during the urea activation period.

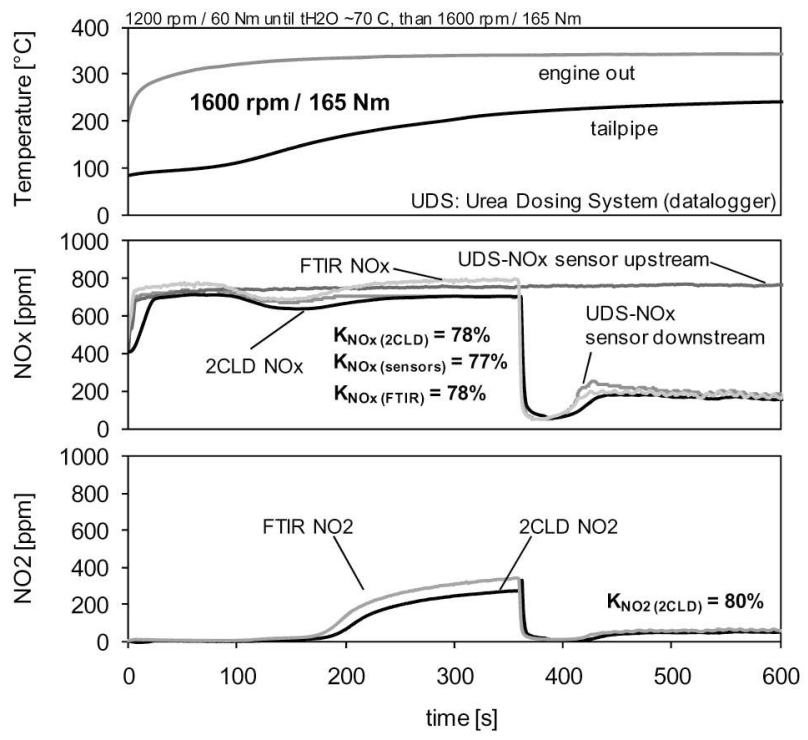

Fig. 9. Estimate of the NOx reduction rate with OEMdatalogging, PF1, $\alpha=0.9$
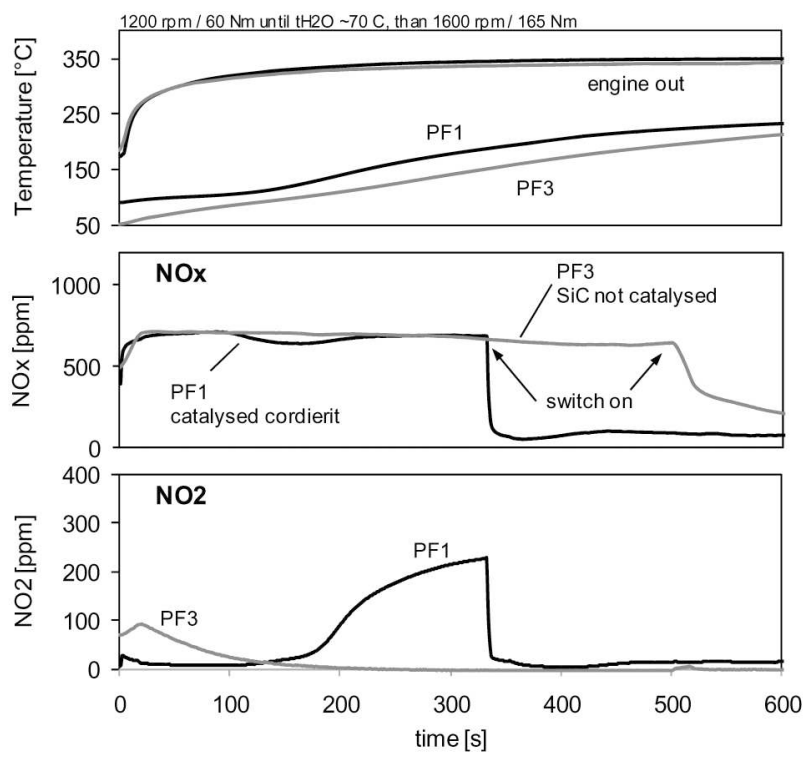

Fig. 10. Comparison of switch on of urea injection with 2 different $P F$
Fig. 9 represents changes of $\mathrm{NO}_{\mathrm{x}}$ and $\mathrm{NO}_{2}$ concentrations over time measured with the OEM-UDS-sensors and with the laboratory equipment (CLD \& FTIR) during an urea switchon test. There are small deviations between the $\mathrm{NO}_{\mathrm{x}}$-readings of the different instruments. The OEM-NO $\mathrm{N}_{\mathrm{x}}$-sensors depict very well the $\mathrm{NO}_{\mathrm{x}}$ conversion rates $\mathrm{K}_{\mathrm{NOX}}$, which are obtained from laboratory analyzers (CLD \& FTIR).

At the operating condition with higher $\mathrm{NO}_{\mathrm{x}}$-concentrations (without urea injection), the FTIR shows higher $\mathrm{NO}_{\mathrm{x}} \& \mathrm{NO}$ concentrations than the CLD. This is due to several reasons, one of them being a much shorter sampling line for FTIR.

We conclude that the original system $\mathrm{NO}_{\mathrm{x}}$-sensors are a well suited to observe the $\mathrm{NO}_{\mathrm{x}}$ conversion rate; they can be recommended as suitable tools for a field control.

Fig. 10 compares SW-tests of PF1, a catalyzed cordierite, with $\mathrm{PF} 3$, a $\mathrm{SiC}$ not catalysed $+\mathrm{FBC}$. Both filters differ in their $\mathrm{NO}_{2}$-emissions in the phase between load jump and the start of the urea injection. The catalysed DPF generates substantial amounts of $\mathrm{NO}_{2}$, whereas the FBC-DPF doesn't. The duration of this phase is also different for both systems most probably because of different conditions of heat transfer and different thermal capacities in the exhaust system.

Fig. 11 shows the repeatability of several switch-on trials (SW12, 13, 14).

During SW12 temperatures were higher at the beginning. This may be a reason for lower concentrations of $\mathrm{NO}_{2}$, formaldehyde, and formic acid in this period. Also the history of the SCR-catalyst can influence its chemistry by variable amounts of residues, or adsorbed substances.

The time period from "load on" to "urea on" varied in the range of $20 \mathrm{~s}$ in these tests.

The $\mathrm{NO}_{\mathrm{x}}$ reduction efficiencies $\mathrm{K}_{\mathrm{NOX}}$ during the urea switchon are also quite repetitive. This procedure can be regarded as a simple check of the SCR system on the HD chassis dynamometer. 

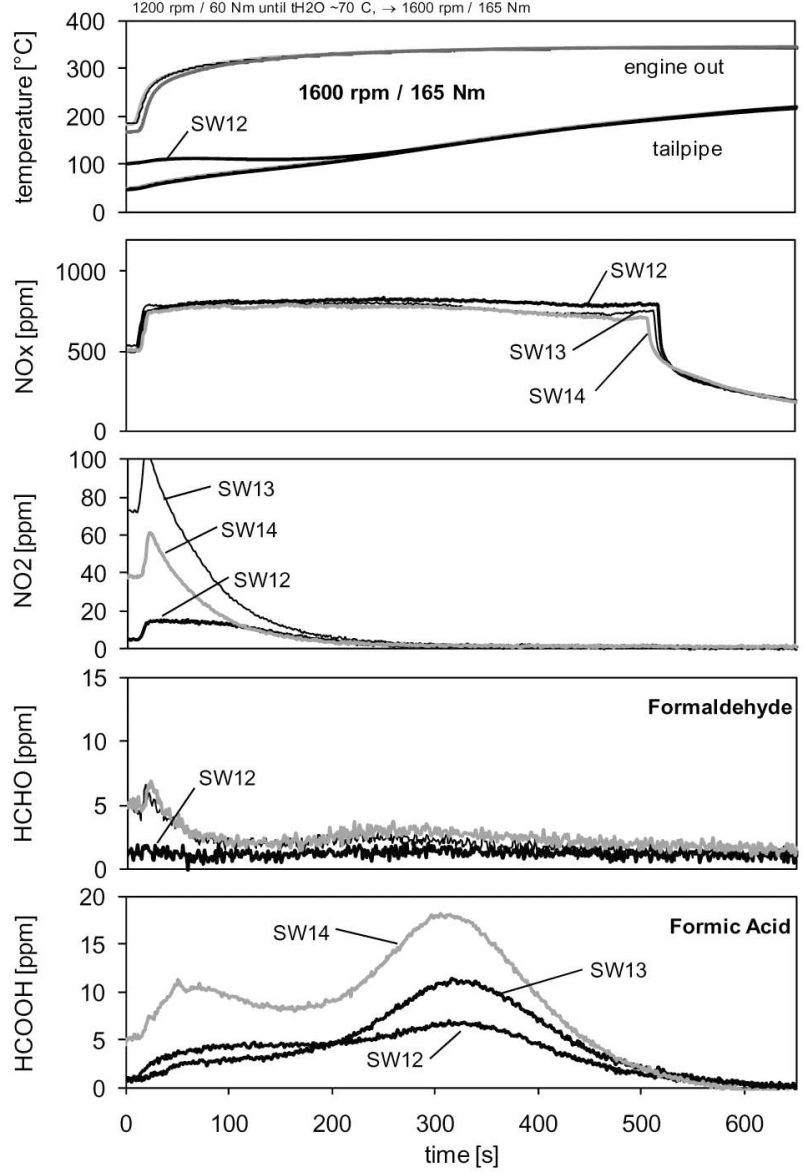

Fig. 11. Repeatability of switch-on tests $(P F 3, \alpha=0.9)$

\section{COMPARISONS OF DIFFERENT} AFTERTREATMENT SYSTEMS

Fig. 12 represents the conversion efficiencies of regulated gaseous components with the investigated aftertreatment systems in the 4-points test.

With uncatalysed PF3, negative CO conversion efficiencies were noticed, mostly at the highest OP, with the highest backpressure. HC is also converted in a vanadium-based SCR-catalyst, and there are as high conversion efficiencies $\mathrm{K}_{\mathrm{HC}}$ in combination with the PF3 system (FBC).
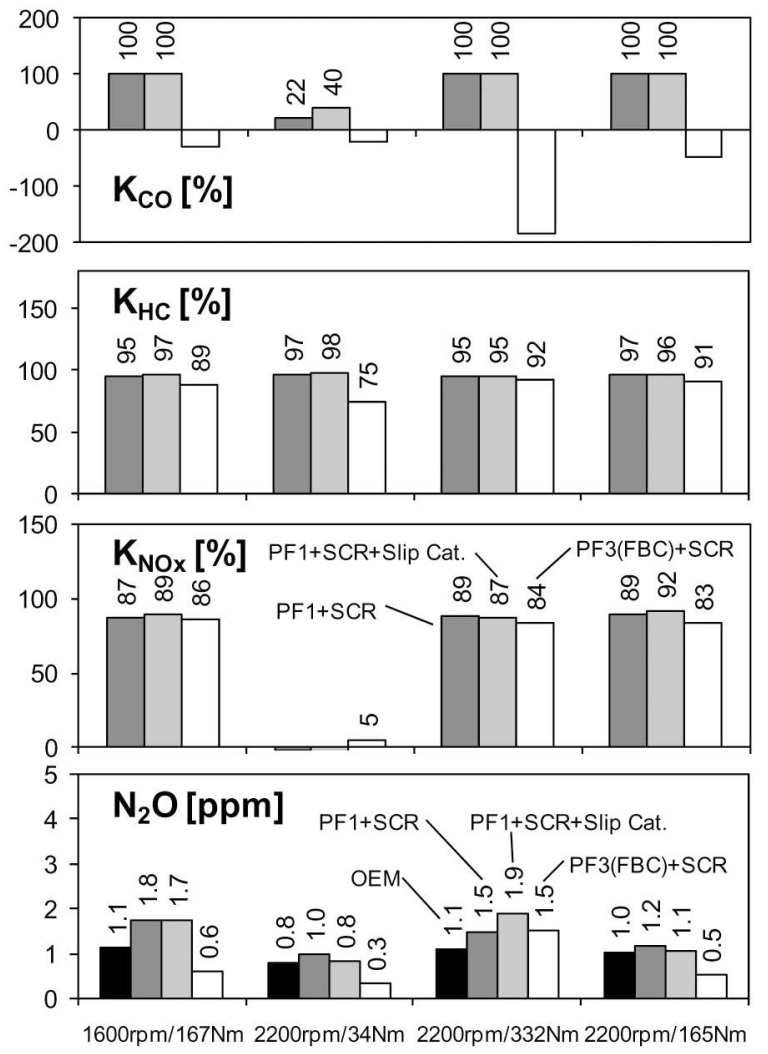

Fig. 12. Conversion efficiencies of regulated pollutants and $\mathrm{N}_{2} \mathrm{O}$ in the 4-points test with different DPF+SCR

systems

$\mathrm{NO}_{\mathrm{x}}$ is not reduced at the lowest OP due to urea switch-off. At higher OP's, with acitve SCR catalyst, there is a tendency of slightly lower $\mathrm{K}_{\mathrm{NOX}}$-values with the fuel-borne catalyzed $\mathrm{PF} 3$. The principal reason is the lower $\mathrm{NO}_{2}$ concentration after this filter.

Emissions of nitrous oxide $\mathrm{N}_{2} \mathrm{O}$ are very low $(<2 \mathrm{ppm})$ and deviate less than $1 \mathrm{ppm}$ from values without aftertreatment (OEM).

Emissions of ammonia $\mathrm{NH}_{3}$ are not represented, since they are generally at zero level, except of one value (10 ppm) for the PF1 (cat.) + SCR at the highest OP (2200 rpm / $332 \mathrm{Nm})$.

Fig. 13 compares the different exhaust aftertreatment systems in the steps-test at $2200 \mathrm{rpm}$. Following effects were observed:

- reduction of $\mathrm{NO}_{\mathrm{x}}$ at $\mathrm{t}_{\mathrm{exh}} \geq 190^{\circ} \mathrm{C}$,

- emission of $\mathrm{NO}_{2}$ increase with PF1 (cat) in the $t_{\text {exh }}$ range $240-340^{\circ} \mathrm{C}$

- emission of $\mathrm{NH}_{3}$ increase up to 8 ppm with $\mathrm{PF} 3$ in the $t_{\text {exh }}$ range $240-340^{\circ} \mathrm{C}$

- emission of $\mathrm{NH}_{3}$ increase up to $10 \mathrm{ppm}$ with PF1 in the $\mathrm{t}_{\text {exh }}$ range $<390^{\circ} \mathrm{C}$ 
- NOx conversion starts at slightly lower $t_{\text {exh }}$, with PF1 than with the fuel-borne catalyzed PF3 $\left(\Delta \mathrm{t} \approx 10-15^{\circ} \mathrm{C}\right)$,

- similar maximum conversion efficiencies $\mathrm{K}_{\mathrm{NOX}}$ were found for both systems.
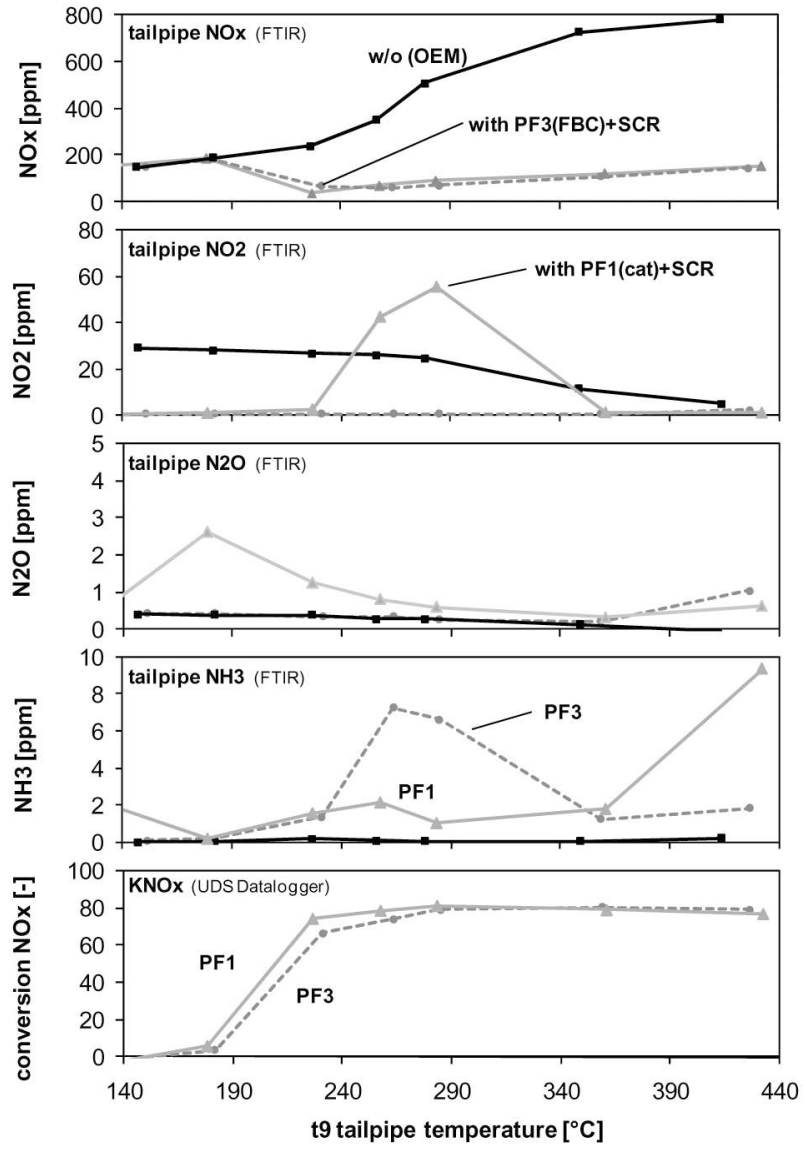

Fig. 13. Comparison of different converter systems in steps-tests at 2200 rpm: Reference - PF1(cat.)+SCR $P F 3(F B C)+S C R, 60$ s average values of stationary operating

\section{CONCLUSIONS}

The most important results from the combined DPF $+\mathrm{SCR}$ systems are summarized as follows:

\section{DIFFERENT TEST CYCLES}

- in the low-load transient cycles (NYCC \& Braunschweig), there are rather low $\mathrm{NO}_{\mathrm{x}}$ conversion efficiencies due to low exhaust gas temperatures and limited urea dosing,

- the SCR-systems in the tested configuration has moderate deNO $\mathrm{x}_{\mathrm{x}}$ efficiencies at low-load city driving, but substantial deNOx efficiencies were found at higher engine loads e.g. at highway conditions

\section{MEASURING TECHNIQUES}

- there are generally good correlations of $\mathrm{NO}_{\mathrm{x}}, \mathrm{NO} \& \mathrm{NO}_{2}$ concentrations measured with CLD and with FTIR; for very low concentrations, after the SCR, the correlations of some parameters become weaker,

- there is a good correlation between $\mathrm{NH}_{3}$ concentrations measured with FTIR and LDS, nevertheless with a clear tendency of higher readings with FTIR; this difference is negligible at concentrations below $10 \mathrm{ppm}$.

- there is a poor correlation of $\mathrm{N}_{2} \mathrm{O}$ levels measured with FTIR and with ULTRAMAT; Both techniques are not sensitive enough to detect $\mathrm{N}_{2} \mathrm{O}$-levels at concentrations below $1 \mathrm{ppm}$.

- the differences are partly caused by differing sampling positions and by differing sampling line lengths,

- relative values, like conversion efficiencies $\mathrm{K}_{\mathrm{x}}$ are well estimated with all measuring methods.

Similar findings are also found in other internal investigations not presented in this paper.

\section{SECONDARY NANOPARTICLES}

- the production of secondary nanoparticles (NP) in the SCRsystem was confirmed; in certain cases, such NP also increase particle mass (PM) emissions to some degree.

\section{UREA SWITCH-ON TESTS}

- the original system $\mathrm{NO}_{\mathrm{x}}$-sensors are valid instruments to determine the $\mathrm{NO}_{\mathrm{x}}$ conversion efficiency; they can be recommended as suitable tools for the field control,

- the repetitive engine load increase during the urea switch-on procedure (SW) was confirmed as a useful way to determine the: switch-on-temperature, switch-on-time and the resulting $\mathrm{NO}_{\mathrm{x}}$ conversion rate,

- with this procedure, response times for deNOx systems up to $8 \mathrm{~min}$ after the load jump were found,

- PF3 with a FBC has a considerably longer response time than coated PF1; different heat transfer and thermal capacity are possible reasons for this difference

- $\mathrm{PF} 3$ with $\mathrm{FBC}$ produces lower $\mathrm{NO}_{2}$ concentrations in the time period from load jump to SCR light-off,

- the switch-on procedure (SW) can be recommended as a simple check of the SCR system on the HD chassis dynamometer. 


\section{COMPARISONS OF DIFFERENT SYSTEMS}

- the DPN system with FBC has a slightly lower NOx conversion than the coated system due to lower $\mathrm{NO}_{2}$-levels,

- the DPN systems with a coated PF1 efficiently lowered CO and $\mathrm{HC}$, but even with an SCR catalyst downstream can produce higher $\mathrm{NO}_{2} / \mathrm{NO}_{\mathrm{x}}$-ratios at certain operating conditions,

- for both systems there are no critical emissions of unregulated components, like ammonia, and nitrous oxide.

\section{ACKNOWLEDGEMENT}

The authors want to express their gratitude for the financial support and realisation of the project to the:

- Swiss Federal Office of Environment BAFU, Mr. D. Zürcher

- Swiss Federal Office for Roads ASTRA, Mr. K. Meyer, Mr. Th. Gasser

- Swiss Occupational Insurance SUVA, Mr. B. Tobler, Mr. S. Siegrist, Mr. M. Brändle

Further thanks are expressed to:

- IVECO Switzerland for the research engine and help with engine setting Mr. M. Signer, Mr. E. Mathis, Mr. R. Zellweger

\section{LITERATURE}

1. www.lowemissionzones.eu

2. Frank, W.; Hüthwohl, G. Maurer, B.: SCR-Technologie für Nutzfahrzeuge. Purem Abgassysteme GmbH, MTZ 9/2004, S. 632

3. Jacob, E.: Ammonia Generators for GD-KAT (advanced SCR) Systems. MAN. 2. Emission Control 2004, TU Dresden 17/18 Juni 2004, S. 358

4. Lambert, C., Hammerle, R., McGill, R., Khair, M. et al., "Technical Advantages of Urea SCR for Light-Duty and Heavy-Duty Diesel Vehicle Applications," SAE Technical Paper 2004-01-1292, 2004, doi:10.4271/2004-01-1292.

5. Hug, H.T., Mayer, A., and Hartenstein, A., "Off-Highway Exhaust Gas After-Treatment: Combining Urea-SCR, Oxidation Catalysis and Traps," SAE Technical Paper 930363, 1993, doi: 10.4271/930363.

6. Hinz, A., Jarvis, T., Abul-Milh, M., Amar, P. et al., "Field Test Trucks Fulfilling EPA '07 Emission Levels On-Road by Utilizing the Combined DPF and Urea-SCR System," SAE Technical Paper 2006-01-0421, 2006, doi: 10.4271/2006-01-0421.
7. Arrowsmith, D., Bott, A., and Bush, P., "Development of a Compact Urea-SCR+CRT ${ }^{\text {TM }}$ System for Heavy-Duty Diesel Using a Design of Experiments Approach," SAE Technical Paper 2006-01-0636, 2006, doi:10.4271/2006-01-0636.

8. Rusch, K., Kaiser, R., and Hackenberg, S., "DPF SCR Combinations Integrated Systems to Meet Future LDV Emission Limits," SAE Technical Paper 2006-01-0637, doi: 10.4271/2006-01-0637.

9. Jacob, E.; Müller, R.; Scheeder, A.; Cartus, T.; Dreisbach, R.; Mai, H.-P.; Paulus, M.; Spengler, J.: High Performance SCR Catalyst System: Elements to Guarantee the Lowest Emissions of $\mathrm{NO}_{\mathrm{x}}$. 27. Internationales Wiener Motorensymposium 2006. Bd.2.

10. Cartus, T.; Schüssler, M.; Herrmuth, H.; Giovanella, M.: SCR and DPF - From Concept to Production. Mastering Complex, Mutli-Dimensional Challenges. 28. Internationales Wiener Motorensymposium 2007. Bd.1.

11. Willems, F., Cloudt, R., van den Eijnden, E., van Genderen, M. et al., "Is Closed-Loop SCR Control Required to Meet Future Emission Targets?," SAE Technical Paper 2007-01-1574, 2007, doi:10.4271/2007-01-1574.

12. Pischinger, S., Körfer, T., Wiartalla, A., Schnitzler, J. et al., "Combined Particulate Matter and NOx Aftertreatment Systems for Stringent Emission Standards," SAE Technical Paper 2007-01-1128, 2007, doi:10.4271/2007-01-1128.

13. Hosoya, M., Kawada, Y., Sato, S., and Shimoda, M., "The Study of NOx and PM Reduction Using Urea Selective Catalytic Reduction System for Heavy Duty Diesel Engine," SAE Technical Paper 2007-01-1576, 2007, doi: 10.4271/2007-01-1576.

14. Görsmann, C.: Retrofit SCRT ${ }^{\circledR}$ - A retrofit system for the simultaneous reduction of carbon monoxide, hydrocarbon, soot particulate and oxides of nitrogen emissions from commercial vehicles, 4. FAD - Konferenz, Dresden, Nov. 2006, p. 155.

15. Mayer, A., Czerwinski, J., Legerer, F., and Wyser, M., "VERT Particulate Trap Verification," SAE Technical Paper 2002-01-0435, 2002, doi:10.4271/2002-01-0435.

16. Mayer, A., Czerwinski, J., Pétermann, J.-L., Wyser, M. et al., "Reliability of DPF-Systems: Experience with 6000 Applications of the Swiss Retrofit Fleet," SAE Technical Paper 2004-01-0076, 2004, doi:10.4271/2004-01-0076.

17. Minimierung der Partikelemissionen von Verbrennungsmotoren. Teil 1: Grundlagen, Wirkungen, Messtechnik und Grenzwerte. München 15. Mai 2006, Veranstaltung Nr. E-H030-05-185-6, Haus der Technik, Essen, www.hdt-essen.de.

18. Sessions: Measurement Technics $\&$ Health Effects, $9^{\text {th }}$ ETH \& $10^{\text {th }}$ ETH Conference on Combustion Generated Particles, Zürich Aug. 15-17. 2005 \& Zürich Aug. 21-23. 2006, www.nanoparticles.ethz.ch 
19. Mayer, A. \& 81 coautors: Elimination of Engine Generated Nanoparticles, Problems and solutions. Haus der Technik Handbuch, Band 58, Expert Verlag 2005, www.expertverlag.de

20. Czerwinski, J., Zimmerli, Y., Mayer, A., Heeb, N. et al., "Testing of Combined DPF+SCR Systems for HDretrofitting VERTdePN," SAE Technical Paper 2009-01-0284, 2009, doi:10.4271/2009-01-0284.

\section{ABBREVIATIONS}

\section{AFHB}

Abgasprüfstelle FH Bid, $\mathrm{CH}$

\section{AKPF}

Arbeitskreis der Partikelfilterhersteller, Austria

Air min

stoichiometric air requirement

\section{ASTRA}

Amt für Strassen, CH, Swiss Road Authority

\section{BAFU}

Bundesamt für Umwelt, CH (Swiss EPA)

\section{CARB}

Californian Air Resources Board

CDI

Common Rail Diesel Injection

\section{CFPP}

cold filter plugging point

\section{CLD}

chemoluminescence detector

\section{$\mathrm{CNC}$}

condensation nuclei counter

\section{CPC}

condensation particle counter

DC

Diffusion Charging Sensor
dePN

de Particles + deNO $_{\mathrm{x}}$

DI

Direct Injection

DMA

differential mobility analyzer

DPF

Diesel Particle Filter

ECU

electronic control unit

\section{EMPA}

Eidgenössische Material Prüf- und Forschungsanstalt

\section{EPA}

Environmental Protection Agency

ETC

European Transient Cycle

FAD

Förderkreis Abgasnachbehandlungs-technologien für Dieselmotoren, Germany

FBC

fuel borne catalyst (regeneration additive)

FE

filtration efficiency

FID

flame ionization detector

FL

full load

FOEN

Federal Office of Environment (BAFU)

FTIR

Fourrier Transform Infrared Spectrometer 
HD

heavy duty

ICE

internal combustion engines

JRC

EU Joint Research Center

LDS

Laser Diode Spectrometer (for $\mathrm{NH}_{3}$ )

LEM

limited engine map

LEZ

low emission zones

LRV

Luftreinhalteverordnung

ME

Matter Engineering

MD19

heated minidiluter

\section{NanoMet}

NanoMetnanoparticle summary surface analyser (PAS

+ DC + MD19)

PAS + DC + sampling \& dilution unit

\section{NEM}

nonlimited engine map

NP

nanoparticles < 999 nm (SMPS range)

NRTC

nonroad transient cycle

NYCC

New York City Cycle

\section{OEM}

original equipment manufacturer
OP

operating point

PAS

Photoelectric Aerosol Sensor

PC

particle counts

PCFE

particle counts filtration efficiency

PF1

DPF catalyzed cordierite

PF3

DPF uncoated $\mathrm{SiC}+\mathrm{FBC}$

PM

particulate matter, particle mass

PMFE

particle mass filtration efficiency

PMP

particle measuring program of the EC GRPE

PSD

particle size distribution

PSI

Paul Scherrer Institute

RE

reduction efficiency

SCR

selective catalytic reduction

SMPS

Scanning Mobility Particle Sizer

SP

sampling position

SUVA

Schweiz. Unfallversicherungs-Anstalt 
SW

urea switch-on

TC

thermoconditioner. Total Carbon

TNO

Netherland National, Laboratories

TÜV

Technischer Überwachungsverein, D

\section{ULSD}

ultra low sulfur Diesel

\section{UMTEC}

Umwelttechnik Institut FH Rapperswil, CH

\section{VERT}

Verminderung der Emissionen von Realmaschinen in Tunelbau

Verification of Emission $\underline{\text { Reduction }}$ Technologies

\section{VERTdePN}

VERT DPF + VERT deNO

\section{VROM}

Netherlands EPA

\section{VSET}

VERT Secondary Emissions Test

\section{WHTC}

worldwide heavy duty transient cycle feed factor of urea dosing;

ratio: urea injected / urea stoichio-metric;

calculated by the ECU. 